Relations industrielles

Industrial Relations

\title{
The Relative Earnings of Visible Minorities in Canada
}

New Evidence from the 1996 Census

Les gains relatifs des minorités visibles au Canada

une nouvelle démonstration à l'aide du recensement de 1996

\section{Los ingresos relativos de las minorías visibles en Canadá} nuevas evidencias provenientes del Censo de 1996

\section{Robert Swidinsky et Michael Swidinsky}

Volume 57, numéro 4, automne 2002

URI : https://id.erudit.org/iderudit/006904ar

DOI : https://doi.org/10.7202/006904ar

Aller au sommaire du numéro

Éditeur(s)

Département des relations industrielles de l’Université Laval

ISSN

0034-379X (imprimé)

1703-8138 (numérique)

Découvrir la revue

Citer cet article

Swidinsky, R. \& Swidinsky, M. (2002). The Relative Earnings of Visible Minorities in Canada: New Evidence from the 1996 Census. Relations industrielles / Industrial Relations, 57(4), 630-659.

https://doi.org/10.7202/006904ar

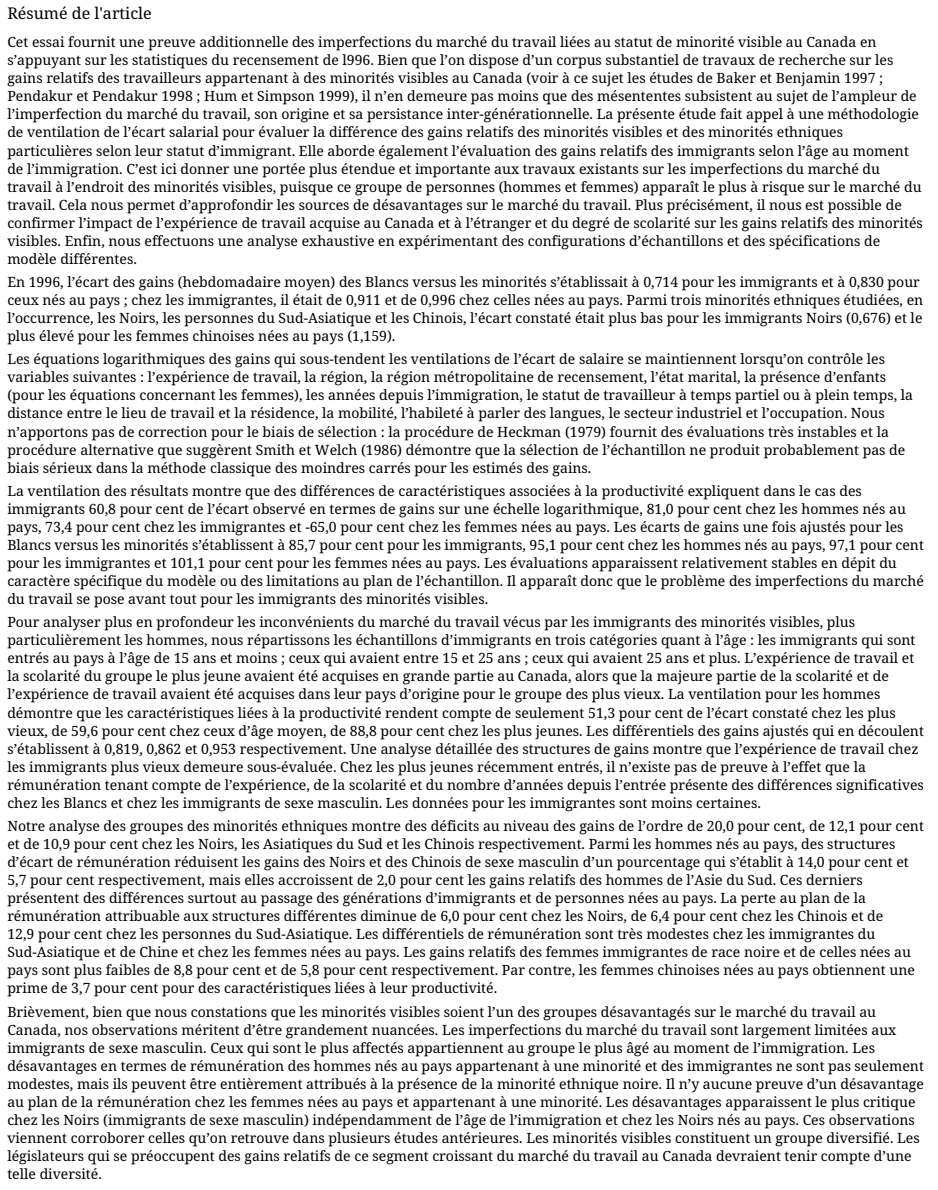

Cet essai fournit une preuve additionnelle des imperfections du marché du travail liées au statut de minorité visible au Canada en gains relatifs des travailleurs appartenant à des minorités visibles au Canada (voir à ce sujet les études de Baker et Benjamin 1997; Pendakur et Pendakur 1998; Hum et Simpson 1999), il n'en demeure pas moins que des mésententes subsistent au sujet de l'ampleur de e ventilation de l'écart salarial pour évaluer la différence des gains relatifs des minorités visibles et des minorités ethniques de l'immigration. C'est ici travail à l'endroit des minorités visibles, puisque ce groupe de personnes (hommes et femmes) apparait le plus à risque sur le marché du

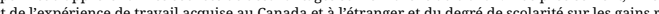

En 1996, l'écart des gains (hebdomadaire moyen) des Blancs versus les minorités s'établissait à 0,714 pour les immigrants et à 0,830 pour ceux nés au pays; chez les immigrantes, il était de 0,911 et de 0,996 chez celles nées au pays. Parmi trois minorités ethniques étudiées, en

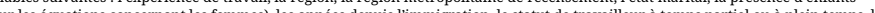
distance entre le lieu de travail et la résidence, la mobilité, l'habileté à parler des langues, le secteur industriel et l'occupation. Nous procédure alternative que sugrèrent Smith e welch (1986) démontre que la sélection de l'échantillon ne produit probablement pas de

La ventiation des resultats montre que des differences de caracteristiques associées a la productivite expliquent dans le cas des immigrants 60,8 pour cent de lécart observe en termes de gains sur une échelle logarithmique, 81,0 pour cent chez les hommes nés au Blancs versus les minorités s'établissent à 85,7 pour cent pour les immigrants, 95,1 pour cent chez les hommes nés au pays, 97,1 pour cent pour les immigrantes et 101,1 pour cent pour les femmes nées au pays. Les évaluations apparaissent relativement stables en dépit du du travail se pose

Pour analyser plus en profondeur les inconvénients du marché du travail vécus par les immigrants des minorités visibles, plus particulierement les hommes, nous répartissons les échantillons dimmigrants en trois categories quant a lâge: les immigrants qui son

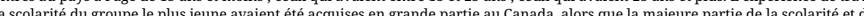
expérience de travail avaient été acquises dans leur pays d'origine pour le groupe des plus vieux. La ventilation pour les hommes veux, de 59,6 pour cent chez ceux d'äge moyen, de 88,8 pour cent chez les plus jeunes. Les differentiels des gains ajustés qui en découlent les immigrt a 0,819, 0,862 et 0,953 respectivement. Une analyse detaillee des structures de gains montre que P'experience de traval lo

Notre analyse des groupes des minorités ethniques montre des déficits au niveau des gains de l'ordre de 20,0 pour cent, de 12,1 pour cent d'écart de rémunér chez les Noirs, les Asiatiques du Sud et les Chinois respectivement. Parmi les hommes nés aul pays, des structures 5,7 pour cent respectivement, mais elles accroissent de 2,0 pour cent les gains relatifs des hommes de l'Asie du Sud. Ces derniers présentent des dirterences surtout au passage des genérations dimmigrants et de personnes nées au pays. La perte au plan de la 12,9 pour cent chez les personnes du Sud-Asiatique. Les différentiels de rémunération sont très modestes chez les immigrantes du Sud-Asiatique et de Chine et chez les femmes nées au pays. Les gains relatiffs des femmes immigrantes de race noire et de celles nées au prime de 3,7 pour cent pour des caractéristiques liées à leur productivité. nent de limmigration. Les modestes, mais ils peuvent être entè̀rement attribués à la présence de la minorité ethnique noire. Il n’y aucune preuve d'un désavantage (a) législateurs qui se préoccupent des gains relatifis de ce segment croissant du marché du travail au Canada devraient tenir compte d'une
Tous droits réservés @ C Département des relations industrielles de l’Universite Laval, 2002
Ce document est protégé par la loi sur le droit d'auteur. L’utilisation des services d’Érudit (y compris la reproduction) est assujettie à sa politique d'utilisation que vous pouvez consulter en ligne.

https://apropos.erudit.org/fr/usagers/politique-dutilisation/ 


\title{
The Relative Earnings of Visible Minorities in Canada
}

\author{
New Evidence from the 1996 Census
}

\author{
ROBERT SWIDINSKY \\ Michael SWidinsky
}

This article presents new evidence on the relative earnings of visible minority immigrant and native-born paid workers in Canada using data from the 1996 Census. Our findings show that labour market disadvantages associated with visible minority status are largely confined to immigrant men. The earnings deficits imputed to minority native-born men and immigrant women are fairly modest, and it appears that native-born women are paid a premium. Among immigrant men, labour market disadvantages are apparent primarily among those who were older when they arrived in Canada. There is some evidence that foreign work experience is relatively undervalued, but there is little evidence that immigrants receive lower compensation for foreign-based schooling. Finally, our analysis of individual ethnic minority groups reveals that Black men are most profoundly affected by labour market discrimination: The earnings deficit they must contend with is both significant and inter-generationally persistent.

There now exists a substantial body of research on the relative earnings of visible minorities in Canada. Most recently, studies by Baker and Benjamin (1997), Pendakur and Pendakur (1998), and Hum and Simpson (1999) appear, in general, to confirm the designation of visible minorities as one of the four disadvantaged groups in the Canadian labour markets. However, there remain disagreements concerning the magnitude of this

- SwIDINSKY, R., Department of Economics, University of Guelph, Guelph, Ontario.

Swidinsky, M., Strategic Policy Branch, Agriculture and Agri-Food Canada, Ottawa, Ontario. 
labour market disadvantage, its inter-generational tenacity, and its source. At least some of the disparate findings may be due to different methodologies, ethnic minority focus groups and data sources.

Baker and Benjamin (1997), for example, investigate the relative earnings of Black, South Asian, Southeast Asian, Chinese and aboriginal immigrant and native-born men using wage-gap decomposition procedures applied to data from the 1991 Census. They find that, among immigrant men, the adjusted minority/white earnings differentials are highest for Chinese (95.6 percent) and lowest for Blacks (80.6 percent). Across generations, from immigrant to native-born, the differentials are essentially static for Black and Chinese men, but substantially higher for Southeast Asian men and substantially lower for South Asian men. While observable differences in productivity-related characteristics explain a substantial component of the raw differentials, the authors note that the persistence of ethnic effects may well reflect embedded discriminatory attitudes that are not easily eradicated.

Pendakur and Pendakur (1997) likewise rely on 1991 Census data for their estimates of ethnic earnings effects, but their analysis, except for the aggregated samples of minority immigrants and Canadian-born individuals, is dependent on single equation log-earnings regressions. For the aggregate samples, wage-gap decomposition results suggest that ethnic effects are strongest among immigrant men and non-existent among Canadianborn women. The results for individual ethnic minority groups are very mixed: among immigrants, the ethnic effects are strongest for Black men and women, but these effects are also acute for a number of detailed ethnic minority groups, including South Asian, West Asian and Vietnamese men and West Asian and Vietnamese women. Their results also show that the economic prospects do not improve markedly, or they may even fall as in the case of Chinese men, between immigrant and native-born generations. However, the sample sizes are too small to yield reliable estimates of intergenerational ethnic effects for most minority ethnic groups. Nonetheless, the findings in Pendakur and Pendakur would appear consistent with the findings in Baker and Benjamin: economic discrimination may play a role in Canadian labour markets. At the very least, although there is considerable heterogeneity among minority ethnic groups, some of these groups must contend with significant negative earnings effects relative to their white counterparts.

Hum and Simpson (1999) sound an even stronger caution against treating visible minorities as a homogeneous group for public policy purposes. They find, using data from the first wave of the Survey of Labour and Income Dynamics and selectivity-corrected log-earnings function estimation procedures, that there are significant wage disadvantages for visible 
minority foreign-born men relative to white foreign-born men. Coefficient estimates indicate an earnings deficit of 23 percent for non-Chinese oriental men, 21 percent for Black men, 16 percent for Chinese men, and 15 percent for Indo-Pakistani men. With the exception of Black men, the coefficient estimates for Canadian-born men are not statistically significant. The estimated earnings deficit for native-born Black men is 24.1 percent, a finding that suggests persisting, and possibly even diverging, Black ethnic earnings effects. However, Hum and Simpson also note that, with the exception of non-Chinese oriental immigrants, there is little statistical evidence suggesting that foreign-born or Canadian-born women experience a significant earnings deficit relative to white women.

This article presents new evidence on the labour market disadvantages associated with visible minority status in Canada using data from the 1996 Census. Our study, which relies on wage-gap decomposition methodology, provides analysts with a longer time frame over which to assess the persistence of wage discrimination against visible minorities. Moreover, not only does our study conduct the usual analysis for visible minority aggregates and selected individual ethnic minorities differentiated by immigrant status, it also investigates the relative earnings of visible minority immigrants differentiated by age at immigration. This is an important extension to existing research on the labour market disadvantages of visible minorities since this group of men and women appears most at risk in the labour markets. It also enables us to probe more deeply into the sources of labour market discrimination. More specifically, it enables us to ascertain the effect of foreign and Canadian-based work experience and schooling on the relative earnings of visible minorities. Finally, because the findings may be sensitive to research methodology, we conduct an exhaustive analysis, experimenting with different model specifications and sample definitions.

We find that, in 1996, labour market disadvantages associated with visible minority status are largely confined to immigrant men. With the exception of the Black ethnic minority, we fail to find inordinately large gaps in earnings between white and visible minority immigrant women, native-born men, or native-born women. Even in the case of immigrant men, labour market disadvantages are apparent primarily among minority men who were older when they immigrated to Canada.

The following section contains a discussion of the data and the earnings model, the third section sets out the OLS earnings estimates, while the fourth section presents the basic earnings-gap decompositions for immigrant and native-born paid workers. The next section presents the decomposition results for individual ethnic minority groups. The findings of this study are summarized in the last section. 


\section{DATA AND MODEL SPECIFICATION}

Data for this study are obtained from the 1996 Census Public Use Microdata File (PUMF) on individuals. To construct the working samples of males and females we retain observations only if the individual is between 15 and 64 years of age, is non-native (i.e., not of Aboriginal origin), was a paid worker (not self-employed) in 1995, had nonzero earnings and weeks of work, was not a student for the past nine months, and did not reside in the Atlantic region, Yukon or the Northwest Territories. This latter exclusion is necessary because several key explanatory variables (e.g., years since migration) are not available or are available in only highly aggregated form for these regions. Although there are sound reasons for limiting the analysis to full-time/full-year paid workers, we do not restrict our working sample to this smaller, more cohesive group; to do so would render the native-born ethnic minority samples too small for meaningful analysis.

The above restrictions result in working samples of 142,459 male paid workers (89.6 percent of whom are white and 10.4 percent visible minorities) and 131,790 female paid workers (89.3 percent of whom are white and 10.7 percent visible minorities). ${ }^{1}$ Table 1 shows that visible minority men are predominantly immigrants. Only 1,595 (10.8 percent) of all visible minority men in the sample are native-born: The remaining 13,214 (89.2 percent) are immigrants. The working sample of minority immigrant men includes 1,953 Black (14.8 percent of the minority immigrant sample), 3,364 Chinese (25.4 percent), 3,257 South Asian (24.6 percent), and 4,640 other and multiple response (35.1 percent) paid workers. ${ }^{2}$ Among native-born minority men the corresponding numbers are 456 Black (28.5 percent of the minority native-born sample), 514 Chinese (32.2 percent), 183 South Asian (11.5 percent), and 442 other and multiple response (27.7 percent) paid workers. The white-minority, native-born-immigrant, and ethnic distributions of the working sample of female paid workers are very similar and do not require additional comment.

1. In the 1996 Census visible minority status is determined through the population group question (Question 19): A visible minority is a person who meets the criteria for inclusion in any of the following groups: Black, South Asian, Chinese, Korean, Japanese, South Asian, Filipino, Arab/West Asian, Latin American, Visible Minority, n.i.e., or Multiple Visible Minority (PUMF, VISMINP-Field 25).

2. There are nine identifiable visible minority ethnic groups in the public use microdata file. However, most ethnic groups had to be excluded from the specific ethnic group analysis because they contain too few observations to allow earnings-gap decomposition analysis. Since these excluded groups are too heterogeneous to be aggregated into meaningful ethnic groups they are combined into the catch-all "other" category. 


\section{TABLE 1}

\section{Sample Size and Weekly Earnings by Immigrant and Visible Minority Status}

\begin{tabular}{|c|c|c|c|c|c|c|}
\hline \multirow[b]{3}{*}{ Sample } & \multicolumn{3}{|c|}{ Male Paid Workers } & \multicolumn{3}{|c|}{ Female Paid Workers } \\
\hline & $\begin{array}{c}\text { Sample } \\
\text { Size }\end{array}$ & $\begin{array}{c}\text { Average } \\
\text { Weekly } \\
\text { Earnings } \\
\$\end{array}$ & $\begin{array}{c}\text { Minority/ } \\
\text { White } \\
\text { Earnings } \\
\text { Differential } \\
\%\end{array}$ & $\begin{array}{c}\text { Sample } \\
\text { Size }\end{array}$ & $\begin{array}{c}\text { Average } \\
\text { Weekly } \\
\text { Earnings } \\
\$\end{array}$ & $\begin{array}{c}\text { Minority/ } \\
\text { White } \\
\text { Earnings } \\
\text { Differential } \\
\%\end{array}$ \\
\hline & (1) & (2) & (3) & (4) & (5) & (6) \\
\hline \multicolumn{7}{|l|}{ Immigrant } \\
\hline White & 16,270 & 922 & - & 14,327 & 571 & - \\
\hline Minority & 13,214 & 658 & 71.4 & 12,668 & 520 & 91.1 \\
\hline Black & 1,953 & 623 & 67.6 & 2,144 & 552 & 96.7 \\
\hline South Asian & 3,257 & 713 & 77.3 & 2,657 & 493 & 86.3 \\
\hline Chinese & 3,364 & 663 & 71.9 & 3,395 & 540 & 94.6 \\
\hline Other & 4,640 & 630 & 68.3 & 4,472 & 504 & 88.3 \\
\hline \multicolumn{7}{|l|}{ Native-Born } \\
\hline White & 111,380 & 810 & - & 103,334 & 545 & - \\
\hline Minority & 1,595 & 672 & 83.0 & 1,461 & 543 & 99.6 \\
\hline Black & 456 & 569 & 70.2 & 392 & 468 & 85.9 \\
\hline South Asian & 183 & 599 & 73.9 & 181 & 446 & 81.8 \\
\hline Chinese & 514 & 721 & 89.0 & 468 & 632 & 115.9 \\
\hline Other & 442 & 750 & 92.6 & 420 & 555 & 101.8 \\
\hline
\end{tabular}

Table 1 also shows that in 1995 the average weekly earnings of visible minority immigrant men were 28.6 percent lower than average weekly earnings of white immigrant men ( $\$ 658$ vs. $\$ 922$ ).

Relative earnings were lowest for Blacks (67.6 percent) and highest for South Asians (77.3 percent). Native-born visible minority men earned an average of $\$ 672$ weekly, or 17.0 percent less than white Canadian-born paid workers. However, the unadjusted relative earnings ranged from 70.2 percent for native-born Blacks to 92.6 percent for other and multiple response visible minority native-born Canadians.

The unadjusted earnings differentials are significantly different for women. While minority immigrant women earn 8.9 percent less than white immigrant women ( $\$ 520$ vs. $\$ 571$ ), native-born minority women earned the same average weekly wage as native-born white women ( $\$ 543$ vs. \$545). Among native-born women the white/minority earnings differential ranges from 81.8 percent for South Asian women to 115.9 percent for 
Chinese women. For immigrants, the corresponding differentials range from 86.3 percent for South Asian women to 96.7 percent for Black women. ${ }^{3}$

OLS earnings equations are estimated separately for the immigrant and native-born samples of paid workers differentiated by visible minority status. ${ }^{4}$ These structural wage equations are used to analyze the observed white-visible minority earnings gaps for the identified groups, using the wage-gap decomposition techniques developed in Oaxaca (1973). The logearnings equations take the form (subscripts for individuals are suppressed):

(1) $\ln \mathrm{E}=\beta \mathrm{X}+\mathrm{u}$

where $\ln \mathrm{E}$ is the natural log of average weekly earnings (annual earnings divided by weeks worked), $\mathrm{X}$ is a row vector of productivity-related explanatory variables, $\beta$ is a vector of corresponding coefficients, and $u$ is an error term. Although annual earnings is generally the preferred specification for the dependent variable, our analysis is based on average weekly earnings; this latter specification eliminates any ambiguity in the interpretation of the decomposition results (see De Silva 1999: 73). The earnings model controls for work experience, region, urban-rural location, marital status, children present (in female equations only), schooling, years since migration (YSM), full-time/part-time (FTPT) status, commuting distance, mobility, language proficiency, industry and occupation. ${ }^{5}$

Most of the explanatory variables are fairly standard and have been used in other relative wage studies that employ census data (see, for example, Shapiro and Stelcner 1987), but several require additional comment. Labour market experience is defined as (age - years of formal schooling 6), but it is well known that the traditional Mincer proxy over-estimates accumulated labour market experience for women. We experimented with an alternative measure of labour market experience for women using an

3. The minority/white earnings differentials show similar patterns if the sample is restricted to full-time/full-year workers, or if earnings are defined as annual earnings.

4. Several studies, for example, Christofides and Swidinsky (1994) and Hum and Simpson (1999), use the conventional Heckman (1979) procedure to correct for sample selection bias. However, as Blau and Beller (1992: 276) note, this procedure has been increasingly criticized for its "lack of robustness." Since we likewise find that our regression results are unstable when the Heckman technique is used to correct for sample selection bias, we experimented with, but do not report, an alternative methodology, a procedure employed in Smith and Welch (1986), to identify potential selectivity bias. Results of our analysis suggest that sample selection is unlikely to cause serious bias in the OLS earnings estimates.

5. The precise definitions of all variables used in the earnings model are available in an appendix upon request from the first author. 
imputational method proposed in Zabalza and Arrufat (1985). ${ }^{6}$ However, since the final estimates of labour market discrimination were affected only marginally by this alternative variable derivation, we present results based only on the Mincer proxy for experience.

Baker and Benjamin (1994) have pointed out that Canadian employers may not attach the same value to education and work experience obtained in the home country as in the adopted country. Although this nonequivalence may simply reflect discriminatory employer behaviour, it may also be a recognition that the human capital acquired in the home-country may have a country-specific component that would be lost on arrival in Canada (Baker and Benjamin 1994: 396). Pendakur and Pendakur (1998) find that employers indeed differentiate between foreign and Canadian schooling, but such differentiation appears very erratic and does not necessarily focus on visible minorities. ${ }^{7}$ However, Hum and Simpson (1999), using data that enables them to distinguish between work experience and schooling acquired in Canada and the home country, find that while education matters regardless of its source, work experience has a positive effect on earnings only if it is obtained in Canada.

Although our data does not permit us to separate foreign and Canadian schooling and work experience, we attempt, following the work in $\mathrm{Li}$ (2001), to test the non-equivalence hypothesis by sorting the sample of immigrants into age groups that would possess entirely Canadian credentials and those whose experience and schooling credentials would be heavily weighted by the home-country. Li (2001), analyzing the market worth of immigrants educational credentials, notes that the older the immigrant on arrival in Canada, the lower the market returns to a university degree. Compared with native-born degree holders, the returns to a university education are lowest for visible minority immigrants who were age 25 and over

6. Essentially, the Zabalza and Arrufat (1985) technique is to model the probability of female employment from cross-sectional survey-period data and to use the estimated coefficients, together with backdated values for time variant characteristics, to predict the annual probability of employment for each individual in the sample backwards through time. Accumulated experience for each individual is derived by summing the predicted probabilities from the survey-period age to the age at completion of schooling. However, this methodology assumes that the estimated relationship underlying an individual's employment status is stable over time: This is unlikely the case for an immigrant woman who has spent most of her post-schooling years in the country of origin.

7. The study finds that for immigrant males, the returns to education are lower if the place of education was central Europe (post-secondary degree) or other Europe (some postsecondary). For female immigrants, returns are lower if place of education was Asia or Africa (post-secondary degree). However, returns for immigrant females are also lower if the place of education was U.S. or U.K. (high school, some post-secondary, and postsecondary degree). 
at immigration and highest for minority immigrants who were under 13 years of age at immigration. Presumably the credentials for the former are primarily foreign and primarily Canadian for the latter.

Several recent studies, for example Rivera-Batiz (1990), have linked the labour market earnings of immigrants with proficiency in the official language of the host country. In our study the two variables designed to capture language proficiency include knowledge of an official language (English, French, English and French, or neither) and usage of a heritage (non-official) language as a common home language. Since census information on official language competence is not objective, our earnings equation includes home language as a check on the self-reported fluency in English or French. It can be safely argued that individuals, but especially immigrants, whose mother tongue is not English or French, and who habitually use a heritage language in their non-work setting, are less likely to have acquired competence in one of the two official languages. Finally, labour supply theory predicts that the reservation wage should rise with fixed time costs of employment: Commuting distance is a proxy for such costs. ${ }^{8}$

Labour market disadvantages can be exhibited through wage discrimination, occupational segregation, or both. In this article we emphasize estimates of labour market discrimination under the assumption that occupational choice is unconstrained; that is, labour market discrimination manifests itself only through the wage structures within occupations. However, we also estimate, but do not report in detail, the degree of labour market discrimination that is exhibited through both wage discrimination and occupational segregation under the assumption that occupational choice is constrained. In the latter estimates the log-earnings equation does not control for industry and occupation. ${ }^{9}$

8. One reader has rightly noted that commuting distance may be a proxy for CMA $\_$Census Metropolitan area) size.

9. We also derived, but do not report because of space considerations, estimates of wage discrimination and occupational segregation using the methodology developed in Brown, Moon and Zoloth (1980). The critical issue in this methodology is the procedure for deriving underlying non-discriminatory occupational structures. We derived nondiscriminatory occupational structures using, alternatively, a multinomial logit model similar to that in Kidd and Shannon (1994), and a model used in Neuman and Silber (1996) which assumes that in the absence of occupational segregation the shares of minority and majority groups in each occupation will be equal to their respective shares in the labour force. Both procedures are problematic, but they yield very similar results: The observed log-earnings differentials, especially for men, are dominated by intra- rather than inter-occupational earnings effects. These findings are generally consistent with the findings reported in Baker and Benjamin (1997), Kidd and Shannon (1994) and Howland and Sakellariou (1993). 


\section{OLS REGRESSION RESULTS}

Estimated OLS earnings equations for all male paid workers, differentiated by immigrant and by visible minority status, are presented in Table 2. Similar estimates for women are presented in Table 3. The overall fit of each reported earnings equation is acceptable given the micro nature of the data, and the estimated coefficients generally have the expected signs and are significant at the 5 percent level. Summarizing the results for immigrant men, labour market experience has a positive, but nonlinear, effect on average weekly earnings, earnings in Ontario are higher than in other regions of Canada, urbanized white immigrants have higher earnings but urbanized minority immigrants have lower earnings, and married, common-law and other (divorced, separated, widowed) marital states are correlated positively with earnings.

TABLE 2

OLS Log-Earnings Regressions by Visible Minority and Immigrant Status: Men

\begin{tabular}{|c|c|c|c|c|}
\hline \multirow[b]{2}{*}{ Variable $^{a}$} & \multicolumn{2}{|c|}{ Immigrant } & \multicolumn{2}{|c|}{ Native-Born $^{c}$} \\
\hline & White & Minority & White & Minority \\
\hline \multirow[t]{2}{*}{ Constant } & $4.6319 *$ & $4.6266^{*}$ & $4.4639 *$ & $4.7855^{*}$ \\
\hline & (47.89) & (33.83) & (110.99) & $(9.81)$ \\
\hline \multirow[t]{2}{*}{ Experience } & $0.0238^{*}$ & $0.0181 *$ & $0.0318 *$ & $0.0406^{*}$ \\
\hline & (11.19) & (6.89) & $(43.40)$ & $(6.07)$ \\
\hline \multirow[t]{2}{*}{ Experience $^{2}$} & $-0.0003 *$ & $-0.0004 *$ & $-0.0005^{*}$ & $-0.0006^{*}$ \\
\hline & $(8.67)$ & $(6.46)$ & $(30.77)$ & $(3.92)$ \\
\hline \multicolumn{5}{|l|}{ Region $^{\mathrm{b}}$} \\
\hline Quebec & $-0.1420 *$ & $-0.2060 *$ & $-0.0847 *$ & $-0.2321 *$ \\
\hline \multirow{2}{*}{ Prairie } & $-0.1447 *$ & $-0.1262 *$ & $-0.1305 *$ & -0.3058 * \\
\hline & $(4.82)$ & $(2.89)$ & $(14.49)$ & $(3.18)$ \\
\hline \multirow[t]{2}{*}{ West } & -0.0256 & -0.0351 & $0.0126 *$ & 0.0259 \\
\hline & $(1.73)$ & $(1.86)$ & $(2.07)$ & $(0.55)$ \\
\hline \multirow[t]{2}{*}{ Urban } & $0.0574 *$ & $-0.1197 *$ & $0.0597 *$ & -0.0713 \\
\hline & $(3.51)$ & $(3.23)$ & (11.90) & (1.11) \\
\hline \multicolumn{5}{|c|}{ Marital Status $^{\mathrm{b}}$} \\
\hline \multirow[t]{2}{*}{ Married } & $0.1993^{*}$ & $0.1177 *$ & $0.2306^{*}$ & $0.1819 *$ \\
\hline & (9.64) & (5.14) & (34.64) & $(3.20)$ \\
\hline \multirow[t]{2}{*}{ Common } & $0.1026^{*}$ & 0.0732 & $0.1384 *$ & -0.0892 \\
\hline & (3.35) & (1.51) & (16.97) & (1.08) \\
\hline \multirow[t]{2}{*}{ Other } & $0.0874^{*}$ & $0.0921 *$ & $0.1064 *$ & 0.0099 \\
\hline & (3.03) & $(2.40)$ & (10.32) & (0.09) \\
\hline \multirow[t]{2}{*}{ YSM } & $0.0142 *$ & $0.0296 *$ & - & - \\
\hline & (7.87) & (10.13) & & \\
\hline
\end{tabular}


TABLE 2 (continued)

\begin{tabular}{|c|c|c|c|c|}
\hline \multirow[b]{2}{*}{ Variable $^{a}$} & \multicolumn{2}{|c|}{ Immigrant } & \multicolumn{2}{|c|}{ Native-Born ${ }^{c}$} \\
\hline & White & Minority & White & Minority \\
\hline $\mathrm{YSM}^{2}$ & $\begin{array}{l}-0.0002 * \\
(6.79)\end{array}$ & $\begin{array}{l}-0.0004 * \\
(4.84)\end{array}$ & - & - \\
\hline \multicolumn{5}{|l|}{ Schooling ${ }^{\mathrm{b}}$} \\
\hline Elementary & $\begin{array}{c}-0.0733 \\
(1.79)\end{array}$ & $\begin{array}{l}0.0162 \\
(0.26)\end{array}$ & $\begin{array}{l}0.1447 * \\
(4.63)\end{array}$ & $\begin{array}{l}0.7192 \\
(1.63)\end{array}$ \\
\hline $9-13$ yrs & $\begin{array}{l}-0.0814 \\
(1.94)\end{array}$ & $\begin{array}{l}0.1089 \\
(1.92)\end{array}$ & $\begin{array}{l}0.2039^{*} \\
(6.82)\end{array}$ & $\begin{array}{l}0.5832 \\
(1.33)\end{array}$ \\
\hline Secondary & $\begin{array}{l}-0.0803 \\
(1.86)\end{array}$ & $\begin{array}{l}0.1547 * \\
(2.65)\end{array}$ & $\begin{array}{l}0.3148 * \\
(10.36)\end{array}$ & $\begin{array}{l}0.6718 \\
(1.79)\end{array}$ \\
\hline Trade & $\begin{array}{l}0.0137 \\
(0.33)\end{array}$ & $\begin{array}{l}0.2338 * \\
(3.89)\end{array}$ & $\begin{array}{l}0.3759 * \\
(12.34)\end{array}$ & $\begin{array}{l}0.7377 \\
(1.95)\end{array}$ \\
\hline Other & $\begin{array}{l}0.0187 \\
(0.44)\end{array}$ & $\begin{array}{l}0.2376^{*} \\
(4.06)\end{array}$ & $\begin{array}{l}0.4027 * \\
(13.20)\end{array}$ & $\begin{array}{c}0.6888 \\
(1.83)\end{array}$ \\
\hline Univ./No degree & $\begin{array}{l}0.0189 \\
(0.41)\end{array}$ & $\begin{array}{l}0.2428 * \\
(4.08)\end{array}$ & $\begin{array}{l}0.4400 * \\
(14.14)\end{array}$ & $\begin{array}{l}0.6831 \\
(1.81)\end{array}$ \\
\hline Bachelor Degree & $\begin{array}{l}0.1832 * \\
(4.02)\end{array}$ & $\begin{array}{l}0.3980 * \\
(6.71)\end{array}$ & $\begin{array}{l}0.6067 * \\
(19.43)\end{array}$ & $\begin{array}{l}0.8994 * \\
(2.39)\end{array}$ \\
\hline Post Graduate & $\begin{array}{l}0.3172 * \\
(6.56)\end{array}$ & $\begin{array}{l}0.5281^{*} \\
(8.03)\end{array}$ & $\begin{array}{l}0.7308 * \\
(22.03)\end{array}$ & $\begin{array}{l}1.0911 * \\
(2.79)\end{array}$ \\
\hline \multicolumn{5}{|c|}{ Language Proficiency ${ }^{\mathrm{b}}$} \\
\hline French & $\begin{array}{l}0.0017 \\
(0.03)\end{array}$ & $\begin{array}{c}-0.0507 \\
(0.89)\end{array}$ & $\begin{array}{l}-0.0371 * \\
(3.18)\end{array}$ & $\begin{array}{l}0.0003 \\
(0.00)\end{array}$ \\
\hline English/French & $\begin{array}{l}0.0232 \\
(1.07)\end{array}$ & $\begin{array}{l}0.0440 \\
(1.32)\end{array}$ & $\begin{array}{l}0.0110 \\
(1.26)\end{array}$ & $\begin{array}{l}0.0170 \\
(0.22)\end{array}$ \\
\hline Neither & $\begin{array}{l}-0.2177 * \\
(4.80)\end{array}$ & $\begin{array}{l}-0.0661 \\
(1.56)\end{array}$ & - & - \\
\hline Home Language & $\begin{array}{l}-0.1734 * \\
(10.65)\end{array}$ & $\begin{array}{l}-0.0708 * \\
(4.04)\end{array}$ & $\begin{array}{c}-0.0488 \\
(1.89)\end{array}$ & $\begin{array}{l}-0.1693 * \\
(2.28)\end{array}$ \\
\hline Mover & $\begin{array}{c}-0.0706 \\
(1.18)\end{array}$ & $\begin{array}{c}-0.1053 \\
(1.17)\end{array}$ & $\begin{array}{l}-0.0601 * \\
(2.95)\end{array}$ & $\begin{array}{l}-0.1936 \\
(1.30)\end{array}$ \\
\hline \multicolumn{5}{|l|}{ Distance $^{\mathrm{b}}$} \\
\hline $5-14 \mathrm{~km}$ & $\begin{array}{l}0.0474 * \\
(3.32)\end{array}$ & $\begin{array}{l}0.0531 * \\
(2.90)\end{array}$ & $\begin{array}{l}0.0409 * \\
(7.33)\end{array}$ & $\begin{array}{l}0.1122 * \\
(2.27)\end{array}$ \\
\hline $15-24 \mathrm{~km}$ & $\begin{array}{l}0.0709 * \\
(3.76)\end{array}$ & $\begin{array}{l}0.0600 * \\
(2.45)\end{array}$ & $\begin{array}{l}0.0682 * \\
(9.16)\end{array}$ & $\begin{array}{l}0.0949 \\
(1.36)\end{array}$ \\
\hline$>24 \mathrm{~km}$ & $\begin{array}{l}0.1212 * \\
(6.34)\end{array}$ & $\begin{array}{l}0.1373 * \\
(4.64)\end{array}$ & $\begin{array}{l}0.0941 * \\
(13.75)\end{array}$ & $\begin{array}{l}0.1879 * \\
(2.40)\end{array}$ \\
\hline Full-Time & $\begin{array}{l}0.6219 * \\
(23.68)\end{array}$ & $\begin{array}{l}0.5722 * \\
(20.01)\end{array}$ & $\begin{array}{l}0.6276^{*} \\
(70.39)\end{array}$ & $\begin{array}{l}0.6223 * \\
(10.39)\end{array}$ \\
\hline $\mathrm{R}^{2}$ & .249 & .216 & .288 & .348 \\
\hline $\mathrm{N}$ & 16,269 & 13,213 & 111,379 & 1,594 \\
\hline
\end{tabular}

${ }^{\text {a }}$ Equations include controls for 25 occupations and 16 industries.

${ }^{\mathrm{b}}$ Omitted categories: Ontario; Single (Never Married); 0-5 yrs; English; 0-4km.

${ }^{c}$ Equations exclude YSM, YSM ${ }^{2}$, Neither.

* Significant at the $5 \%$ level. t-scores are given in brackets. 
TABLE 3

OLS Log-Earnings Regressions by Visible Minority and Immigrant Status: Women

\begin{tabular}{|c|c|c|c|c|}
\hline \multirow[b]{2}{*}{ Variable $^{a}$} & \multicolumn{2}{|c|}{ Immigrant } & \multicolumn{2}{|c|}{ Native-Born $^{c}$} \\
\hline & White & Minority & White & Minority \\
\hline Constant & $\begin{array}{l}4.6979 * \\
(41.92)\end{array}$ & $\begin{array}{l}4.4283 * \\
(25.93)\end{array}$ & $\begin{array}{l}4.2364 * \\
(78.95)\end{array}$ & $\begin{array}{l}4.0005^{*} \\
(6.88)\end{array}$ \\
\hline Experience & $\begin{array}{l}0.0210^{*} \\
(8.40)\end{array}$ & $\begin{array}{l}0.0182 * \\
(6.82)\end{array}$ & $\begin{array}{l}0.0276^{*} \\
(33.75)\end{array}$ & $\begin{array}{l}0.0307 * \\
(4.87)\end{array}$ \\
\hline Experience $^{2}$ & $\begin{array}{l}-0.0004 * \\
(7.13)\end{array}$ & $\begin{array}{l}-0.0003^{*} \\
(4.69)\end{array}$ & $\begin{array}{l}-0.0005^{*} \\
(24.71)\end{array}$ & $\begin{array}{l}-0.0005^{*} \\
(3.03)\end{array}$ \\
\hline \multicolumn{5}{|l|}{ Region $^{\mathrm{b}}$} \\
\hline Quebec & $\begin{array}{l}-0.1775^{*} \\
(6.22)\end{array}$ & $\begin{array}{l}-0.1538^{*} \\
(4.55)\end{array}$ & $\begin{array}{l}-0.0774 * \\
(7.60)\end{array}$ & $\begin{array}{l}-0.0509 \\
(0.57)\end{array}$ \\
\hline Prairie & $\begin{array}{l}-0.1751 * \\
(5.03)\end{array}$ & $\begin{array}{l}-0.2062^{*} \\
(4.87)\end{array}$ & $\begin{array}{l}-0.1294 * \\
(14.07)\end{array}$ & $\begin{array}{c}-0.1451 \\
(1.49)\end{array}$ \\
\hline West & $\begin{array}{l}-0.0431 * \\
(2.60)\end{array}$ & $\begin{array}{c}-0.0131 \\
(0.71)\end{array}$ & $\begin{array}{l}-0.0186 * \\
(2.93)\end{array}$ & $\begin{array}{l}0.0100 \\
(0.22)\end{array}$ \\
\hline Urban & $\begin{array}{l}0.1072 * \\
(5.84)\end{array}$ & $\begin{array}{l}-0.0034 \\
(0.08)\end{array}$ & $\begin{array}{l}0.0794 * \\
(15.15)\end{array}$ & $\begin{array}{l}0.0634 \\
(1.00)\end{array}$ \\
\hline \multicolumn{5}{|l|}{ Marital Status ${ }^{\mathrm{b}}$} \\
\hline Married & $\begin{array}{l}-0.0090 \\
(0.33)\end{array}$ & $\begin{array}{l}0.0642 * \\
(2.63)\end{array}$ & $\begin{array}{l}0.0610 * \\
(7.66)\end{array}$ & $\begin{array}{l}0.1707^{*} \\
(3.05)\end{array}$ \\
\hline Common & $\begin{array}{c}-0.0163 \\
(0.45)\end{array}$ & $\begin{array}{l}0.0955 \\
(1.90)\end{array}$ & $\begin{array}{l}0.0560 * \\
(6.25)\end{array}$ & $\begin{array}{l}0.0953 \\
(1.16)\end{array}$ \\
\hline Other & $\begin{array}{l}-0.0310 \\
(1.00)\end{array}$ & $\begin{array}{l}0.0259 \\
(0.82)\end{array}$ & $\begin{array}{l}0.0406^{*} \\
(4.09)\end{array}$ & $\begin{array}{l}0.1621 \\
(1.93)\end{array}$ \\
\hline YSM & $\begin{array}{l}0.0140 * \\
(6.62)\end{array}$ & $\begin{array}{l}0.0250^{*} \\
(8.40)\end{array}$ & - & - \\
\hline $\mathrm{YSM}^{2}$ & $\begin{array}{l}-0.0002 * \\
(5.04)\end{array}$ & $\begin{array}{l}-0.0004 * \\
(4.58)\end{array}$ & - & - \\
\hline \multicolumn{5}{|l|}{ Schooling $^{\mathrm{b}}$} \\
\hline Elementary & $\begin{array}{l}-0.0225 \\
(0.46)\end{array}$ & $\begin{array}{l}0.0820 \\
(1.37)\end{array}$ & $\begin{array}{l}0.3132 * \\
(7.32)\end{array}$ & $\begin{array}{l}0.7319 \\
(1.78)\end{array}$ \\
\hline Grade 9-13 & $\begin{array}{l}-0.0800 \\
(1.58)\end{array}$ & $\begin{array}{l}0.1321^{*} \\
(2.27)\end{array}$ & $\begin{array}{l}0.3607 * \\
(8.84)\end{array}$ & $\begin{array}{l}0.9805^{*} \\
(2.83)\end{array}$ \\
\hline Secondary & $\begin{array}{c}-0.0063 \\
(0.12)\end{array}$ & $\begin{array}{l}0.2089 * \\
(3.53)\end{array}$ & $\begin{array}{l}0.4294 * \\
(10.52)\end{array}$ & $\begin{array}{l}1.1326 * \\
(3.29)\end{array}$ \\
\hline Trade & $\begin{array}{l}-0.0398 \\
(0.75)\end{array}$ & $\begin{array}{l}0.2181 * \\
(3.43)\end{array}$ & $\begin{array}{l}0.4509 * \\
(10.91)\end{array}$ & $\begin{array}{l}0.9876^{*} \\
(2.81)\end{array}$ \\
\hline Other & $\begin{array}{l}0.0234 \\
(0.45)\end{array}$ & $\begin{array}{l}0.2931 * \\
(4.90)\end{array}$ & $\begin{array}{l}0.5300^{*} \\
(12.96)\end{array}$ & $\begin{array}{l}1.1563^{*} \\
(3.38)\end{array}$ \\
\hline $\begin{array}{l}\text { University/ } \\
\text { No Degree }\end{array}$ & $\begin{array}{l}0.0865 \\
(1.60)\end{array}$ & $\begin{array}{l}0.3480^{*} \\
(5.65)\end{array}$ & $\begin{array}{l}0.6055^{*} \\
(14.64)\end{array}$ & $\begin{array}{l}1.2620^{*} \\
(3.66)\end{array}$ \\
\hline
\end{tabular}


TABLE 3 (continued)

\begin{tabular}{|c|c|c|c|c|}
\hline \multirow[b]{2}{*}{ Variable $^{a}$} & \multicolumn{2}{|c|}{ Immigrant } & \multicolumn{2}{|c|}{ Native-Born $^{c}$} \\
\hline & White & Minority & White & Minority \\
\hline Bachelor Degree & $\begin{array}{l}0.2194 * \\
(4.01)\end{array}$ & $\begin{array}{l}0.4624 * \\
(7.53)\end{array}$ & $\begin{array}{c}0.7794 * \\
(18.77)\end{array}$ & $\begin{array}{l}1.4007 * \\
(4.08)\end{array}$ \\
\hline Post Graduate & $\begin{array}{l}0.3455^{*} \\
(5.75)\end{array}$ & $\begin{array}{l}0.5982 * \\
(8.00)\end{array}$ & $\begin{array}{l}0.9309 * \\
(21.15)\end{array}$ & $\begin{array}{l}1.5993 * \\
(4.45)\end{array}$ \\
\hline \multicolumn{5}{|c|}{ Language Proficiency ${ }^{\mathrm{b}}$} \\
\hline French & $\begin{array}{l}0.0332 \\
(0.66)\end{array}$ & $\begin{array}{c}-0.0152 \\
(0.26)\end{array}$ & $\begin{array}{l}-0.0325^{*} \\
(2.70)\end{array}$ & $\begin{array}{c}-0.2166 \\
(0.93)\end{array}$ \\
\hline English/French & $\begin{array}{l}0.0480 * \\
(2.04)\end{array}$ & $\begin{array}{l}0.0791 * \\
(2.27)\end{array}$ & $\begin{array}{l}0.0029 \\
(0.33)\end{array}$ & $\begin{array}{c}-0.0078 \\
(0.12)\end{array}$ \\
\hline Neither & $\begin{array}{l}-0.2135^{*} \\
(4.07)\end{array}$ & $\begin{array}{c}-0.0893 * \\
(2.29)\end{array}$ & - & - \\
\hline Home Language & $\begin{array}{l}-0.0763 * \\
(4.01)\end{array}$ & $\begin{array}{l}-0.0600 * \\
(3.42)\end{array}$ & $\begin{array}{l}-0.1382 * \\
(4.75)\end{array}$ & $\begin{array}{c}-0.0495 \\
(0.65)\end{array}$ \\
\hline Mover & $\begin{array}{l}-0.2385^{*} \\
(2.94)\end{array}$ & $\begin{array}{c}-0.3954^{*} \\
(4.15)\end{array}$ & $\begin{array}{l}-0.0896^{*} \\
(3.85)\end{array}$ & $\begin{array}{l}-0.2095 \\
(1.46)\end{array}$ \\
\hline \multicolumn{5}{|l|}{ Distance $^{\mathrm{b}}$} \\
\hline $5-14 \mathrm{~km}$ & $\begin{array}{l}-0.0860 * \\
(5.66)\end{array}$ & $\begin{array}{l}0.0840 * \\
(4.72)\end{array}$ & $\begin{array}{l}0.0750 * \\
(13.38)\end{array}$ & $\begin{array}{l}0.0172 \\
(0.38)\end{array}$ \\
\hline $15-24 \mathrm{~km}$ & $\begin{array}{l}0.1533^{*} \\
(6.64)\end{array}$ & $\begin{array}{l}0.0948^{*} \\
(3.72)\end{array}$ & $\begin{array}{l}0.0968 * \\
(12.04)\end{array}$ & $\begin{array}{l}0.0987 * \\
(1.44)\end{array}$ \\
\hline$>24 \mathrm{~km}$ & $\begin{array}{l}0.1325^{*} \\
(5.21)\end{array}$ & $\begin{array}{l}0.0580 \\
(1.69)\end{array}$ & $\begin{array}{l}0.1168 * \\
(14.13)\end{array}$ & $\begin{array}{l}0.0900 \\
(1.05)\end{array}$ \\
\hline Full-Time & $\begin{array}{l}0.5762 * \\
(35.37)\end{array}$ & $\begin{array}{l}0.4636^{*} \\
(22.48)\end{array}$ & $\begin{array}{l}0.5704 * \\
(100.11)\end{array}$ & $\begin{array}{l}0.6206^{*} \\
(12.97)\end{array}$ \\
\hline \multicolumn{5}{|l|}{ Children $^{\mathrm{b}}$} \\
\hline Child $(<6)$ & $\begin{array}{c}-0.0218 \\
(0.86)\end{array}$ & $\begin{array}{c}-0.0003 \\
(0.01)\end{array}$ & $\begin{array}{l}-0.0004 \\
(0.05)\end{array}$ & $\begin{array}{c}-0.0664 \\
(1.01)\end{array}$ \\
\hline Child (6-14) & $\begin{array}{l}-0.0451 * \\
(2.11)\end{array}$ & $\begin{array}{l}-0.0751 * \\
(2.97)\end{array}$ & $\begin{array}{l}-0.0673 * \\
(8.79)\end{array}$ & $\begin{array}{l}-0.1676 * \\
(2.14)\end{array}$ \\
\hline Child (> 14) & $\begin{array}{l}-0.0265 \\
(1.43)\end{array}$ & $\begin{array}{l}-0.0549 * \\
(2.07)\end{array}$ & $\begin{array}{l}-0.0393 * \\
(5.06)\end{array}$ & $\begin{array}{c}-0.1567 \\
(1.67)\end{array}$ \\
\hline $\mathrm{R}^{2}$ & .265 & .196 & .314 & .365 \\
\hline $\mathrm{N}$ & 14,326 & 12,667 & 103,333 & 1,460 \\
\hline
\end{tabular}

a Equations include controls for 25 occupations and 16 industries.

${ }^{\mathrm{b}}$ Omitted categories: Ontario; Single (Never Married); 0-5 yrs; English; 0-4 km, No Children.

${ }^{c}$ Equations exclude YSM, YSM ${ }^{2}$, Neither.

* Significant at the 5\% level. t-scores are given in brackets.

Our results also show that years since migration has a positive, but nonlinear, effect on the weekly earnings of immigrant men; schooling, 
especially at the university level, is associated with higher earnings, and immigrants who lack proficiency in either of the official languages have lower average weekly earnings than immigrants who have made an investment in one of the official languages. Finally, interprovincial mobility is not a significant determinant, but fixed time-costs and full-time status are both correlated positively with weekly earnings.

Several of these results, however, merit additional comment. An additional year of work experience has a significantly greater impact on the earnings of white immigrants. To illustrate, the $5^{\text {th }}$ year of experience would raise the earnings of white immigrant men by roughly 2 percent compared with 1.5 percent for minority immigrant men; the $20^{\text {th }}$ year of experience would raise weekly earnings by 1 and .4 percent, respectively. On the other hand, an additional year since immigrating to Canada increases the weekly earnings of visible minority men by more than twice the increase for white men. As well, schooling, especially at the university level, has a much stronger effect on the weekly earnings of minority than white immigrant men. For example, an undergraduate degree increases the earnings of minority immigrants by 39.8 percent compared with 18.3 percent for white immigrants.

Since the regression results for native-born men essentially resemble the results for immigrant men, there is little to be gained from detailed discussion. It should be noted, however, that not only are the returns to schooling, as in the immigrant results, higher for minority men than for white men, but the marginal effects of work experience, contrary to the immigrant results, are also slightly higher. Although there are several interesting variations, the estimated immigrant and native-born regressions for women yield results that are essentially the same as those presented for men. The most notable difference is that the effects of work experience are very similar for white and minority women in both immigrant and native-born regressions.

\section{DECOMPOSITION RESULTS}

While the immigrant and native-born OLS regression results for both men and women show marked differences in the pay structures for several of the productivity-related characteristics of white and visible minority paid workers, the two groups also differ in the average endowments of productivity characteristics. For example, as Table 4 shows, visible minorities, whether immigrant or native born, have fewer years of labour market experience than white men and women, but they are more likely to have a university education. As well, mean years since migration are significantly lower for visible minorities than for white immigrants. These endowment 
differences may provide a partial explanation of the observed earnings differentials between white and minority paid workers. The Oaxaca (1973) decomposition expression (2) provides a convenient method for decomposing algebraically the observed earnings gaps into a portion attributable to differences in average characteristics and a portion attributable to differences in labour market compensation for each characteristic. The algebraic expression is given as:

(2) $\quad \ln \mathbf{E}^{\mathrm{w}}-\ln \mathbf{E}^{\mathrm{v}}=\Sigma_{\mathrm{i}}\left(\mathbf{X}_{\mathrm{i}}^{\mathrm{w}}-\mathbf{X}_{\mathrm{i}}^{\mathrm{v}}\right) \beta_{\mathrm{i}}^{\mathrm{w}}+\Sigma_{\mathrm{i}}\left(\beta_{\mathrm{i}}^{\mathrm{w}}-\beta_{\mathrm{i}}^{\mathrm{v}}\right) \mathbf{X}_{\mathrm{i}}^{\mathrm{v}}$

where $\ln \mathrm{E}$ is the log of earnings, $\beta_{\mathrm{i}}$ is the estimated coefficient for the $\mathrm{i}^{\text {th }}$ characteristic $\mathrm{X}_{\mathrm{i}}$, and superscripts $\mathrm{w}$ and $\mathrm{v}$ refer to white and visible minority workers, respectively. Bold script indicates the mean of a variable. The regression constants are included in the second term on the right-hand side. The first, or explained, component measures the cumulative, intergroup, differences in the means of the independent variables weighted by the estimated regression coefficients of the group (e.g. white immigrants) with higher observed average earnings. The latter, or unexplained, component measures the cumulative inter-group differences in the coefficients of the estimated earnings equations weighted by the means of the disadvantaged group's (e.g. visible minority immigrants) independent variables. ${ }^{10}$ It is this latter, unexplained component which has been associated with wage discrimination. ${ }^{11}$

The earnings-gap decompositions for the aggregated samples are reported in Table 5. Column 2 shows the proportion of the observed mean log-earnings gap (given in column 1) that is explained by differences in productivity characteristics; the proportion attributable to differences in rewards to productivity characteristics is not shown since it is merely the

10. Expression (2) assumes that in the absence of racial discrimination the visible minority pay structure would resemble the white pay structure. However, it is conceivable that in the absence of discrimination the white pay structure would resemble the minority pay structure so that the weights in the decomposition expression should be reversed. Most likely, in the absence of labour market discrimination, the prevailing pay structure would lie between the white and minority pay structures, and it is the elements of this non-discriminatory pay structure that should enter as weights in the endowment component of the wage gap decomposition. Cotton (1988) suggests that a non-discriminatory pay structure can be constructed by taking the weighted average of the white and minority pay structures, using sample proportions as weights. This averaging procedure, however, makes only marginal differences to our estimates. Consequently, we do not report these results.

11. Estimates of labour market discrimination derived from wage-gap decomposition analysis must be viewed with some degree of caution. The analysis has to contend with measurement errors, inadequate information and omitted variables, all of which may result in less than accurate estimates of labour market discrimination. 
residual of the former. Column 3, however, gives the adjusted minority/ white earnings differential derived from the unexplained component. ${ }^{12}$

TABLE 4

Sample Means of Selected Variables

\begin{tabular}{lrrrc}
\hline & \multicolumn{4}{c}{ Male Paid Workers } \\
\cline { 2 - 5 } Variable & \multicolumn{3}{c}{ Immigrant } & \multicolumn{2}{c}{ Native-Born } \\
\cline { 2 - 5 } & White & Minority & White & Minority \\
\hline Experience & 25.346 & 19.481 & 19.055 & 11.669 \\
Bachelors Degree & 0.127 & 0.192 & 0.126 & 0.221 \\
Post Graduate & 0.080 & 0.069 & 0.035 & 0.038 \\
YSM & 25.382 & 13.377 & - & - \\
Neither & 0.021 & 0.048 & - & - \\
Home Language & 0.238 & 0.544 & 0.008 & 0.088 \\
Full-Time $_{\text {Managerial/Professional }}{ }^{\mathrm{a}}$ & 0.944 & 0.913 & 0.920 & 0.805 \\
Blue Collar $^{\mathrm{b}}$ & 0.411 & 0.391 & 0.383 & 0.471 \\
& 0.391 & 0.368 & 0.406 & 0.252 \\
\hline
\end{tabular}

Female Paid Workers

\begin{tabular}{lrrrr} 
& \multicolumn{2}{c}{ Immigrant } & \multicolumn{2}{c}{ Native-Born } \\
\cline { 2 - 5 } Variable & White & Minority & White & Minority \\
\hline Experience & 24.531 & 19.600 & 18.707 & 11.355 \\
Bachelors Degree & 0.137 & 0.194 & 0.147 & 0.275 \\
Post Graduate & 0.054 & 0.032 & 0.024 & 0.032 \\
YSM & 25.147 & 13.575 & - & - \\
Neither & 0.021 & 0.062 & - & - \\
Home Language & 0.223 & 0.487 & 0.007 & 0.076 \\
Full-Time $_{\text {Managerial/Professional }^{\mathrm{a}}}$ & 0.741 & 0.807 & 0.723 & 0.723 \\
Blue Collar $^{\mathrm{b}}$ & 0.583 & 0.515 & 0.640 & 0.669 \\
\hline
\end{tabular}

${ }^{\text {a }}$ Sum of occupations coded 1-11.

${ }^{\mathrm{b}}$ Sum of occupations coded 19-25.

Rows 1(a-d) present the basic wage-gap decomposition results (i.e., results based on regressions reported in Tables 2 and 3). Endowment differences account for more than half ( 60.8 percent) of the observed white/ minority earnings differentials for all immigrant male paid workers: The

12. The unexplained or adjusted minority/white earnings differential is the exp (-unexplained component). 
TABLE 5

Decomposition of Observed Mean Log-Earnings Differentials

\begin{tabular}{ccc}
\hline Observed Log- & Percent & Adjusted Earnings \\
Earnings & Explained & Differential \% \\
Differential & & \\
\hline
\end{tabular}

Comparison Group

(1)

(2)

(3)

1. All Paid Workers
a) Immigrant Men
.3933
60.8
85.7
b) Native-Born Men
.2659
81.0
95.1
c) Immigrant Women
.1111
73.4
97.1
d) Native-Born Women
$-.0060$
$-65.0$
101.0

2. All Paid Workers (Distance, Hours, Children Variables Excluded)
a) Immigrant Men
.3933
61.5
85.9
b) Native-Born Men
.2659
80.6
95.0
c) Immigrant Women
.1111
79.2
97.7
d) Native-Born Women
$-.0060$
$-23.6$
100.7

3. All Paid Workers (Annual Earnings)
a) Immigrant Men
.4489
65.8
85.8
b) Native-Born Men
.3650
85.4
94.8
c) Immigrant Women
.1695
85.5
97.6
d) Native-Born Women
.0463
115.3
100.7

4. All Paid Workers (Industry / Occupation Excluded)
a) Immigrant Men
.3933
50.7
82.4
b) Native-Born Men
.2659
75.9
93.8
c) Immigrant Women
.1111
60.8
95.7
d) Native-Born Women
$-.0060$
$-149.2$
100.7

5. FTFY Paid Workers
a) Immigrant Men
.3726
58.3
85.6
b) Native-Born Men
.1141
43.7
93.8
c) Immigrant Women
.1858
78.7
96.1
d) Native-Born Women
$-.0472$
98.0
100.1

6. All Paid Workers (Immigrant Men)
a) Age at Immigration (25+) $\quad .4095$
51.3
81.9
b) Age at Immigration (16-24) $\quad .3688$
59.6
86.2
c) Age at Immigration $(15-) \quad .4260$
88.8
95.3

7. All Paid Workers (Immigrant Women)
a) Age at Immigration (25+) $\quad .0976$
71.5
97.3
b) Age at Immigration (16-24)
.0599
$-7.1$
93.8
c) Age at Immigration (15 - ) .1004
85.7
98.6 
unexplained component accounts for the remaining 39.2 percent of the observed differential: It implies an adjusted minority/white earnings ratio of 85.7 percent. Several details associated with these results are of particular interest. For example, while the returns to work experience and fulltime work status tend to be lower for minority immigrant men, the returns to education and YSM tend to be higher. More than 80 percent of the observed log-earnings differential for native-born men can be explained by differences in productivity-related characteristics: 19.0 percent of the differential is attributable to a different minority-white pay structure. Nonetheless, minority males tend to earn higher returns to work experience and university education. Accounting for differences in productivity characteristics raises the native-born minority/white earnings differential from 83.0 to 95.1 percent.

Row 1(c) shows that the observed earnings differential between minority and white immigrant women is due largely to differences in mean productivity characteristics. The earnings of minority immigrant women are only 2.9 percent lower than the earnings of white immigrant women once these differences are taken into account. The analysis for native-born women is somewhat more complicated. Although native-born minority women actually earn marginally more than white native-born women, the relative distribution of endowments suggests that their weekly earnings should have been marginally lower. ${ }^{13}$ Had the pay structures for white and minority women been the same, the weekly earnings of minority nativeborn women would have been roughly one percent lower. However, the observed log-earnings differential and the estimated explained and unexplained components are exceedingly small, and it is difficult to have much confidence in the results.

Our aggregated sample results are consistent with the earnings-gap decomposition results reported in the earlier Pendakur and Pendakur (1998) study which draws on data from the 1991 Census. In 1991, visible minority immigrant men reportedly had an earnings deficit of 14.2 percent relative to their white counterparts, ${ }^{14}$ a finding virtually identical to that in the present study based on 1996 Census data. They estimate somewhat higher

13. Although they do not differentiate between foreign and native-born women, Carlson and Swartz (1988) also find that some minority women in the United States (Asian Indians, Chinese, Filipinos, Japanese, Koreans and Cubans) earned more than white women. Not only did these minority women possess superior productive characteristics, but the respective estimated earnings equations showed that they were also paid more than white women for these characteristics.

14. Since the comparison group in the Pendakur and Pendakur study is Canadian-born white men, the 14.2 percent deficit is the difference between the deficit reported for minority immigrant men (15.3 percent) and white immigrant men (1.1 percent). 
earnings deficits for native-born minority men ( 8.3 versus 4.9 percent) and immigrant minority women (7.4 versus 2.9 percent): These comparisons suggest an upward trend in the relative earnings of these two visible minority groups. Native-born women appear to enjoy an earnings surplus of roughly one percent, a finding consistent with that reported in the present study.

The findings reported in rows 1 (a-d), Table 5, suggest that the question of labour market disadvantages arises primarily among visibly minority immigrant men. There appears to be remarkable stability in this result regardless of model specifications and sample restrictions. ${ }^{15}$ The decomposition results, reported in rows 2 (a-d), are basically unaffected when the potentially contentious distance, mover and children (for women) variables are excluded from the earnings regression model. ${ }^{16}$ The wage-gap decomposition results also appear largely unaffected by the re-specification of the earnings variable to annual earnings. The results reported in rows 3(ad) show that, although the observed differential and the corresponding explained component are higher for all groups, the effects of wage discrimination on the earnings of visible minority paid workers are almost identical to the basic results in rows 1(a-d). The observed log-earnings differentials for all four comparison groups appear to be dominated by intrarather than inter-occupational earnings effects. This result is consistent with the findings reported in Baker and Benjamin (1997) and Howland and Sakellariou (1993). As rows 4(a-d) show, the unexplained component of the observed differential tends to rise for all comparison groups, but the effect of occupational segregation on the earnings of visible minorities, with the exception of immigrant men, is fairly modest. For immigrant men occupational segregation reduces relative earnings by roughly 3.3 percent. Finally, except for native-born men, the decomposition results are not significantly different when the sample analyzed is restricted to full-time/fullyear paid workers (rows 5(a-d)). Although the proportion of the observed earnings differential that can be explained by differences in productivityrelated characteristics falls sharply for native-born males, because the observed differential is relatively small, the effect of wage discrimination on the relative earnings of FTFY native-born minority men is fairly modest.

15. Because they are numerous, the log-earnings regressions underpinning the alternative wage-gap decompositions discussed below are not presented; they are nonetheless very similar to regressions for the aggregate samples.

16. The decomposition results remain remarkably stable even when the earnings equation is stripped down to the essential experience, regional, years since migration, schooling and full-time variables. For example, differences in productivity-related factors still explain 50.7 percent of the observed log-earnings differential for immigrant men, and the adjusted minority/white earnings differential falls only from 85.9 to 82.7 percent. 
To explore the sources of the labour market disadvantages experienced by visible minority immigrants, especially men, we partitioned the samples of white and minority immigrants into three categories contingent on age at immigration: Immigrants aged 15 and under, immigrants aged 16-24, and immigrants aged 25 and over. ${ }^{17} \mathrm{We}$ focus on the youngest and oldest groups. Most of the schooling and work experience of the former group would have been acquired in Canada, whereas most of the schooling and a significant portion of the work experience of the latter group would have been acquired in the home country. If employers regard the work experience and education that visible minority immigrants acquire in the home country to be relatively inferior, this attitude should manifest itself in the estimated log-earnings equations and the ensuing wage-gap decomposition results.

The decomposition results for immigrant men reported in 6(a-c) support the non-equivalence hypothesis. Productivity-related characteristics explain only 51.3 percent of the observed log-earnings differential between white and minority immigrants who were 25 or older at arrival, 59.6 percent for immigrants 16-24 at arrival, and 88.8 percent for immigrants 15 or younger at arrival. Had the pay structures for white and minority immigrant men been identical the relative weekly earnings of the younger and older arrival groups of visible minority men would have been higher by 4.7 and 18.1 percent, respectively. A detailed examination of the white/ minority pay structures shows that the work experience of older arrival visible minority immigrants is significantly undervalued relative to that of white immigrants. ${ }^{18}$ There is, however, no evidence that compensation for schooling or years in Canada is lower. For the younger arrival group, there is no evidence that compensation for experience, schooling or years since migration is significantly different for white and minority immigrant men. This finding is not only consistent with the finding, based on the same

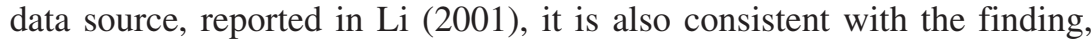
based on detailed information on the amount of foreign and Canadian experience and schooling, reported in Hum and Simpson (1999).

The wage decomposition results for immigrant women segregated by age at immigration are less definitive. Nonetheless, the results reported in panel 7(a-c), show that the explained component is significantly lower for the oldest arrival than for the youngest arrival group (71.5 vs. 85.7 percent): The corresponding adjusted minority/white earnings differentials are,

17. Li (2001), as well as Baker and Benjamin (1994), conduct similar analyses for all immigrants.

18. The estimated coefficient for work experience is 0.0111 and significant for white immigrants but 0.0043 and not significant for visible minority immigrants. 
however, only marginally different (97.3 and 98.6 percent, respectively). The unexpected and highly suspect result for the 16-24 year group is likely due to the very small observed earnings differential that is being decomposed. As with immigrant men, our results show that the work experience, but not education or years since migration, of older arrival visible minority women is significantly undervalued. For the under 15 year group, there are no significant differences between white and minority women in compensation for experience or schooling.

\section{ANALYSIS OF INDIVIDUAL ETHNIC MINORITY GROUPS}

Although the aggregated results suggest that, with the exception of immigrant men, the earnings deficits associated with visible minority status are fairly modest, certain ethnic groups may face significant earnings deficits relative to their white counterparts. Information contained in the 1996 Census PUMF on Individuals enables us to categorize visible minorities into three ethnic origin groups: Black, South Asian, and Chinese. Unlike Baker and Benjamin (1997), we restrict the ethnic samples to individuals who provide single responses to the ethnic origin question. ${ }^{19}$ The earnings-gap decomposition results derived from white and ethnic-specific OLS earnings equations are presented in Table $6 .{ }^{20}$ The underlying OLS equations are too numerous to report: However, it should be noted that, as in Baker and Benjamin (1997), many of the estimated coefficients in the ethnic-specific equations are not statistically significant. ${ }^{21}$

19. Because the allocation of multiple response individuals into specific ethnic groups is such a murky area we opt for caution and, unlike Baker and Benjamin (1997), focus on only single response individuals. However, the total samples of immigrant and nativeborn visible minorities include individuals who gave single or multiple responses to the ethnic origin question.

20. Stelcner and Kyriazis (1995) contend that analyses of labour market discrimination should take into account the heterogeneity among both the visible minority and white comparator groups. Our analysis ignores the possibility that the white majority immigrant group may also be heterogeneous. Such analysis is beyond the scope of this article. However, Pendakur and Pendakur (1998) take such heterogeneity into account. They find significant variations in earnings deficits among individual white ethnic groups.

21. For example, focusing on the two critical variables, work experience and schooling, our regression results show that experience has a statistically significant effect only for Chinese and South Asian immigrant and native-born men, South Asian native-born women, and Black and Chinese immigrant women. University schooling has a statistically significant effect only for Black and Chinese immigrant men, Chinese and South Asian native-born women, and Black and Chinese immigrant women. 
TABLE 6

Decomposition of Observed Mean Log-Earnings Differentials for Selected Ethnic Minorities

\begin{tabular}{|c|c|c|c|}
\hline & $\begin{array}{c}\text { Observed Log- } \\
\text { Earnings } \\
\text { Differential } \\
\end{array}$ & $\begin{array}{l}\text { Percent } \\
\text { Explained }\end{array}$ & $\begin{array}{c}\text { Adjusted Earnings } \\
\text { Differentials } \\
(\%)\end{array}$ \\
\hline Comparison Group & (1) & (2) & (3) \\
\hline \multicolumn{4}{|l|}{ 1. Immigrant Men } \\
\hline Black & .4223 & 47.2 & 80.0 \\
\hline South Asian & .3225 & 59.9 & 87.9 \\
\hline Chinese & .3616 & 68.2 & 89.1 \\
\hline \multicolumn{4}{|l|}{ 2. Native-Born Men } \\
\hline Black & .4439 & 66.0 & 86.0 \\
\hline South Asian & .4278 & 104.7 & 102.0 \\
\hline Chinese & .1384 & 57.7 & 94.3 \\
\hline \multicolumn{4}{|l|}{ 3. Immigrant Women } \\
\hline Black & .0761 & -20.6 & 91.2 \\
\hline South Asian & .1308 & 74.6 & 96.7 \\
\hline Chinese & .0751 & 98.4 & 99.9 \\
\hline \multicolumn{4}{|c|}{ 4. Native-Born Women } \\
\hline Black & .1722 & 65.3 & 94.2 \\
\hline South Asian & .2464 & 79.2 & 95.0 \\
\hline Chinese & -.2103 & 82.7 & 103.7 \\
\hline \multicolumn{4}{|c|}{ 5. Immigrant Men (15-) } \\
\hline Black & .4757 & 79.8 & 90.8 \\
\hline South Asian & .26505 & 105.6 & 101.5 \\
\hline Chinese & .2835 & 111.7 & 103.4 \\
\hline \multicolumn{4}{|c|}{ 6. Immigrant Men (16-24) } \\
\hline Black & .3889 & 43.5 & 80.3 \\
\hline South Asian & .2881 & 71.9 & 92.2 \\
\hline Chinese & .3524 & 58.2 & 86.3 \\
\hline \multicolumn{4}{|c|}{ 7. Immigrant Men (25+) } \\
\hline Black & .4281 & 31.7 & 74.6 \\
\hline South Asian & .3691 & 47.8 & 82.5 \\
\hline Chinese & .3978 & 65.4 & 87.1 \\
\hline
\end{tabular}

Differential white-minority pay structures for Black, South Asian and Chinese immigrant men imply adjusted minority/white earnings differentials of 80.0, 87.9 and 89.1 percent (or earnings deficits of 20.0, 12.1, and 10.9 percent) for the three minority ethnic groups, respectively. Among 
native-born men, differential pay structures reduce the relative earnings of Black and Chinese men by 14.0 and 5.7 percent, respectively, but increase the relative earnings of South Asian men by 2.0 percent. South Asian men differ most across immigrant and native-born generations. The deficit in earnings attributable to different pay structures falls by 6 percent for Blacks, 6.4 percent for Chinese, and 12.9 percent for South Asians. Except for native-born South Asians, our findings are very similar to the findings reported in Baker and Benjamin (1997). The relatively minor discrepancies in the estimated ethnic effects may be due to differences in the choice of earnings (average weekly versus annual) or identification of ethnic minorities (inclusion or exclusion of individuals who have multiple ethnic origins). However, the two studies yield vastly different estimates of the earnings deficit for native-born South Asians: While we find that the earnings of native-born South Asians converge sharply with the earnings of whites, Baker and Benjamin (1997) find a sharp divergence. The findings in Pendakur and Pendakur (1998) are more consistent with our findings, but it should be noted that all three estimates are based on very small sample sizes.

Significantly, there is broad support for the finding that Black men, whether immigrant or native-born, not only face the largest earnings deficit but also the smallest inter-generational improvement in their economic position. Baker and Benjamin (1997) (specification 3) estimate earnings deficits of 19.4 and 15.7 percent, respectively, for immigrant and nativeborn men, Pendakur and Pendakur (1998), 22.2 and 17.4 percent, respectively, and Hum and Simpson (1999), 21.3 and 24.1 percent, respectively. It thus appears that there has been little change between 1991-96 in the relative returns Black men receive for their productivity-related characteristics.

The earnings effects of differential pay structures are relatively modest for South Asian and Chinese immigrant and native-born women. However, the relative earnings of Black immigrant and native-born women are lower by 8.8 and 5.8 percent, respectively, due to less favourable pay structures. By contrast, native-born Chinese women receive a 3.7 percent premium for their productivity characteristics. The increase in the inter-generational earnings deficit for South Asian women is atypical and inconsistent with the findings reported in Pendakur and Pendakur (1998). However, both findings are highly suspect because of small sample size.

There appears no readily obvious pattern to the white-minority differences in the pay structures of Black, Chinese and South Asian immigrant men: Blacks have relatively lower returns to work experience and full-time status, Chinese to full-time status, and South Asians to schooling, full-time status and YSM. However, among native-born men, returns to schooling 
are lower for all three minority ethnic groups: The returns are especially low for Black native-born men. Chinese women, whether immigrant or native-born, tend to have higher returns to schooling relative to their white counterparts.

Since some of the ethnic-specific wage-gap decomposition results are derived from estimated equations that have small sample size and limited explanatory power, we also estimated separate log-earnings regressions with intercept-shift dummy variables representing individual ethnic minorities for all immigrant men, immigrant women, native-born men and nativeborn women. The estimated coefficients for the Black, South Asian and Chinese ethnic identifiers in each of the four equations are reported in Table 7: They are remarkably consistent with the implications of the decomposition results reported in column 3, Table 6. Black, South Asian and Chinese immigrant men, Black immigrant women, and Black native-born men have significantly lower earnings than corresponding white paid workers. Except for Black men, there is little evidence that the ethnic effects observed for immigrants persist into the native-born generation.

Rows 5-7, Table 6, provide additional information on the nature of the labour market disadvantages encountered by immigrant men. Chinese, South Asian, and, especially, Black immigrants who were aged 25+ at arrival all suffer significant losses in earnings $(12.9,17.5$, and 25.4 percent, respectively). By contrast, among immigrants who were aged 15 or under at arrival, only Blacks appear to be affected by wage discrimination. Surprisingly, this wage disadvantage is not as pronounced as the disadvantage encountered by native-born Blacks. The single equation ethnic group estimated coefficients reported in Table 7 corroborate these findings. Similar decomposition results are not reported for women; the small observed differentials and sample sizes yield very unstable results. However, single equation estimates reported in the lower panel of Table 7 show that earnings are significantly lower only for Black immigrant women who were $16-24$ or $25+$ years old at the time of immigration.

\section{SUMMARY AND CONCLUSIONS}

This study employs wage-gap decomposition procedures to analyze observed differentials in average weekly earnings between white and visible minority paid workers using data from the 1996 Census Public Use Microdata File on Individuals. The central question is whether visible minority men and women are denied fair opportunities for full economic participation in the workplace. Although visible minorities, along with women, aboriginal peoples and persons with disabilities, have been designated as being disadvantaged in the labour markets, critics of the 
TABLE 7

Visible Minority Ethnic Group Estimated Coefficients and t-Statistics Derived from Single Equation Models

\begin{tabular}{cccc}
\hline \multirow{2}{*}{ Sample } & \multicolumn{3}{c}{ Paid Male Workers } \\
\cline { 2 - 4 } Native-Born & Black & Chinese & South Asian \\
\multirow{2}{*}{ Immigrant } & $-0.148^{*}$ & -0.056 & -0.022 \\
& $(4.2)$ & $(1.7)$ & $(0.4)$ \\
Immigrant & $-0.207^{*}$ & $-0.114^{*}$ & $-0.116^{*}$ \\
0-15 years & $(10.1)$ & $(6.3)$ & $(6.7)$ \\
& & & 0.025 \\
16-24 years & $-0.113^{*}$ & $(0.6)$ & 0.017 \\
& $(2.8)$ & $0.166^{*}$ & $-0.076^{*}$ \\
25+ years & $-0.213^{*}$ & $(4.8)$ & $(2.3)$ \\
& $(5.3)$ & $-0.131^{*}$ & $-0.183^{*}$ \\
\hline
\end{tabular}

Paid Female Workers

\begin{tabular}{llcc}
\cline { 2 - 4 } Sample & Black & Chinese & South Asian \\
\hline Native-Born & -0.058 & 0.036 & -0.052 \\
& $(1.5)$ & $(1.0)$ & $(0.9)$ \\
Immigrant & $-0.078^{*}$ & 0.022 & -0.023 \\
Immigrant & $(3.8)$ & $(1.2)$ & $(1.2)$ \\
0-15 years & & & \\
16-24 years & 0.069 & 0.010 & 0.013 \\
& $(1.6)$ & $(0.2)$ & $(0.29)$ \\
25+ years & $-0.081^{*}$ & -0.001 & -0.041 \\
& $(2.2)$ & $(0.0)$ & $(1.3)$ \\
& $-0.117 *$ & 0.031 & -0.047 \\
\hline
\end{tabular}

*Denotes significance at the 5 percent level.

Employment Equity Act (Bill C62) have challenged the "fundamental premise of employment equity programs, namely that inequalities exist between groups and reflect systemic discrimination" (Boyd 1992: 281). ${ }^{22}$

Our findings, which are generally consistent with the findings in earlier studies, affirm the designation of visible minorities as one of the disadvantaged groups in the Canadian labour market, but not without major

22. For critical comments, see Loney (1998). 
qualifications. Minority immigrant men experience a significant wage disadvantage relative to white immigrant men: The observed white-minority earnings differential cannot be justified by differences in relative endowments of productivity-related characteristics. The wage disadvantages of minority native-born men and immigrant women are not only modest, they are almost entirely attributable to the Black ethnic minority. There is no evidence of wage discrimination for native-born minority women. These basic findings are not undermined by different methodologies, model specifications, or sample definitions.

We also find that wage disadvantages are far more pronounced among visible minority immigrant men who were older at the time of immigration. This finding is not conditional on ethnic origin. Visible minority women who were older when they immigrated must likewise contend with wage discrimination, but such discriminatory behaviour appears to be directed largely against Black women. The available evidence suggests that the foreign work experience of older visible minority immigrant men and women is relatively undervalued; there is, however, little evidence to suggest that visible minority immigrant men or women receive lower compensation for foreign-based schooling than white immigrant men. These findings, although they need far more exploration and elaboration, suggest that public policy designed to achieve racial wage equality in the labour market should perhaps focus on the integration of older minority immigrants into the Canadian labour market.

Our findings suggest that, in general, the labour market disadvantages associated with visible minority status are not so profound that they warrant deep concerns about racial divisions in our society. There are, indeed, aggregate and individual ethnic earnings effects, but they are not homogeneous, ranging from an earnings deficit of 20.0 percent for Black immigrant men to an earnings premium of 3.7 percent for native-born Chinese women. Moreover, where they do exist, such earnings disadvantages are generally not persistent: They tend to be substantially moderated when transmitted across generations. There are nonetheless individual minorities that have to contend with significant wage discrimination in their labour market activities. The earnings deficits appear to be particularly acute for the Black ethnic minority. Wage discrimination persists among Black immigrant men regardless of age at immigration, among Black native-born men, and, to a lesser extent, among Black immigrant women. The tenacity of this labour market disadvantage is disturbing and needs to be explored in much more detail.

Our findings reinforce the observations made in several earlier studies: the labour market experiences of Canadians who are visible minorities are not homogeneous. This implies that public policy strategies, for example, 
employment equity programs, which focus on labour market discrimination need to be more precisely structured. They need to target immigrants and ethnic minorities most susceptible to discriminatory labour market practices.

\section{】 REFERENCES}

Baker, M. and D. Benjamin. 1994. "The Performance of Immigrants in the Canadian Labor Market.” Journal of Labor Economics, Vol. 12, No. 2, 369405.

BAKeR, M. and D. Benjamin. 1997. "Ethnicity, Foreign Birth and Earnings: A Canada/U.S. Comparison." Transition and Structural Change in the North American Labour Market. M. G. Abbott, C. M. Beach and R. P. Chaykowski, eds. Kingston: IRC Press, Industrial Relations Centre, Queen's University, 281-313.

Baker, M. and D. Benjamin. 1994. "The Performance of Immigrants in the Canadian Labor Market." Journal of Labor Economics, Vol. 12, No. 2, 369405.

BlaU, F. D. and A. H. Beller. 1992. "Black-White Earnings over the 1970s and 1980s: Gender Differences in Trends." Review of Economics and Statistics, Vol. LXXIV, No. 2, 276-286.

BoYD, M. 1992. "Gender, Visible Minority and Immigrant Earnings Inequality: Reassessing an Employment Equity Premise." Deconstructing a Nation: Immigration, Multiculturalism and Racism in the 1990s Canada. V. Satzewich, ed. Toronto: Garamond Press, 279-321.

Brown, R. S., M. Moon and B. S. Zoloth. 1980. "Occupational Attainment and Segregation by Sex." Industrial and Labor Relations Review, Vol. 33, No. 4, 506-517.

CARlson, L. A. and C. Swartz. 1988. "The Earnings of Women and Ethnic Minorities, 1959-1979." Industrial and Labor Relations Review, Vol. 41, No. 4, 530-546.

Christofides, L. N. and R. Swidinsky. 1994. "Wage Determination by Gender and Visible Minority Status: Evidence from the 1989 LMAS." Canadian Public Policy / Analyse de Politiques, Vol. XX, No. 1, 34-51.

CotTon, J. 1988. "On the Decomposition of Wage Differentials." The Review of Economics and Statistics, Vol. 70, No. 2, 236-243.

De Silva, A. 1999. "Wage Discrimination and Natives." Canadian Public Policy / Analyse de Politiques, Vol. XXV, No. 1, 65-85.

Heckman, J. J. 1979. "Sample Selection Bias as a Specification Error." Econometrica, Vol. 47, No. 1, 153-161.

Howland, J. and C. SAKellariou. 1993. "Wage Discrimination, Occupational Segregation and Visible Minorities in Canada." Applied Economics, Vol. 25, 1413-1422. 
Hum, D. and W. Simpson. 1999. "Wage Opportunities for Visible Minorities in Canada." Canadian Public Policy / Analyse de Politiques, Vol. XXV, No. 3, 379-394.

KidD, M. P. and M. ShannON. 1994. "An Update and Extension of the Canadian Evidence on Gender Wage Differentials." Canadian Journal of Economics, Vol. XXVII, No. 4, 918-938.

LI, P. S. 2001. "The Market Worth of Immigrants' Educational Credentials." Canadian Public Policy / Analyse de Politiques, Vol. XXVII, No. 1.

Loney, M. 1998. The Pursuit of Divisions. Montreal and Kingston: McGillQueen's University Press.

Neuman, S. and J. G. Silber. 1996. "Wage Discrimination Across Ethnic Groups: Evidence From Israel.” Economic Inquiry, Vol. XXXIV, October, 648-661.

OAXACA, R. 1973. "Male-Female Wage Differentials in Urban Labor Markets." International Economics Review, Vol. 14, No. 3, 693-709.

Pendakur, K. and R. Pendakur. 1998. "The Colour of Money: Earning Differentials among Ethnic Groups in Canada." Canadian Journal of Economics, Vol. 31, No. 1, 518-548.

RiverA-BAtiz, F. L. 1990. "English Language Proficiency and the Economic Progress of Immigrants.” Economics Letters, Vol. 34, 295-300.

Shapiro, D. M. and M. Stelcner. 1987. "The Persistence of the Male-Female Earnings Gap in Canada, 1970-1980: The Impact of Equal Pay Laws and Language Policies." Canadian Public Policy / Analyse de Politiques, Vol. XIII, No. 4, 462-476.

Smith, J. P. and F. R. Welch. 1986. Closing the Gap: Forty Years of Economic Progress for Blacks. Santa Monica: The Rand Corporation.

Stelcner, M. and N. KYriazis. 1995. "An Empirical Analysis of Earnings among Ethnic Groups in Canada." International Journal of Contemporary Sociology, Vol. 32, No. 1, 40-79.

Zabalza, A. and J. Arrufat. 1985. "The Extent of Sex Discrimination in Great Britain." Women and Equal Pay: The Effects of Legislation on Female Employment and Wages in Britain. A. Zabalza and Z. Tzannatos, eds. Cambridge, Cambridge University Press, 70-96.

\section{RÉSUMÉ}

\section{Les gains relatifs des minorités visibles au Canada : une nouvelle démonstration à l'aide du recensement de 1996}

Cet essai fournit une preuve additionnelle des imperfections du marché du travail liées au statut de minorité visible au Canada en s'appuyant sur les statistiques du recensement de 1996. Bien que l'on dispose d'un corpus 
substantiel de travaux de recherche sur les gains relatifs des travailleurs appartenant à des minorités visibles au Canada (voir à ce sujet les études de Baker et Benjamin 1997 ; Pendakur et Pendakur 1998 ; Hum et Simpson 1999), il n'en demeure pas moins que des mésententes subsistent au sujet de l'ampleur de l'imperfection du marché du travail, son origine et sa persistance inter-générationnelle. La présente étude fait appel à une méthodologie de ventilation de l'écart salarial pour évaluer la différence des gains relatifs des minorités visibles et des minorités ethniques particulières selon leur statut d'immigrant. Elle aborde également l'évaluation des gains relatifs des immigrants selon l'âge au moment de l'immigration. C'est ici donner une portée plus étendue et importante aux travaux existants sur les imperfections du marché du travail à l'endroit des minorités visibles, puisque ce groupe de personnes (hommes et femmes) apparaît le plus à risque sur le marché du travail. Cela nous permet d'approfondir les sources de désavantages sur le marché du travail. Plus précisément, il nous est possible de confirmer l'impact de l'expérience de travail acquise au Canada et à l'étranger et du degré de scolarité sur les gains relatifs des minorités visibles. Enfin, nous effectuons une analyse exhaustive en expérimentant des configurations d'échantillons et des spécifications de modèle différentes.

En 1996, l'écart des gains (hebdomadaire moyen) des Blancs versus les minorités s'établissait à 0,714 pour les immigrants et à 0,830 pour ceux nés au pays ; chez les immigrantes, il était de 0,911 et de 0,996 chez celles nées au pays. Parmi trois minorités ethniques étudiées, en l'occurrence, les Noirs, les personnes du Sud-Asiatique et les Chinois, l'écart constaté était plus bas pour les immigrants Noirs $(0,676)$ et le plus élevé pour les femmes chinoises nées au pays $(1,159)$.

Les équations logarithmiques des gains qui sous-tendent les ventilations de l'écart de salaire se maintiennent lorsqu'on contrôle les variables suivantes : l'expérience de travail, la région, la région métropolitaine de recensement, l'état marital, la présence d'enfants (pour les équations concernant les femmes), les années depuis l'immigration, le statut de travailleur à temps partiel ou à plein temps, la distance entre le lieu de travail et la résidence, la mobilité, l'habileté à parler des langues, le secteur industriel et l'occupation. Nous n'apportons pas de correction pour le biais de sélection : la procédure de Heckman (1979) fournit des évaluations très instables et la procédure alternative que suggèrent Smith et Welch (1986) démontre que la sélection de l'échantillon ne produit probablement pas de biais sérieux dans la méthode classique des moindres carrés pour les estimés des gains.

La ventilation des résultats montre que des différences de caractéristiques associées à la productivité expliquent dans le cas des immigrants 
60,8 pour cent de l'écart observé en termes de gains sur une échelle logarithmique, 81,0 pour cent chez les hommes nés au pays, 73,4 pour cent chez les immigrantes et $-65,0$ pour cent chez les femmes nées au pays. Les écarts de gains une fois ajustés pour les Blancs versus les minorités s'établissent à 85,7 pour cent pour les immigrants, 95,1 pour cent chez les hommes nés au pays, 97,1 pour cent pour les immigrantes et 101,1 pour cent pour les femmes nées au pays. Les évaluations apparaissent relativement stables en dépit du caractère spécifique du modèle ou des limitations au plan de l'échantillon. Il apparaît donc que le problème des imperfections du marché du travail se pose avant tout pour les immigrants des minorités visibles.

Pour analyser plus en profondeur les inconvénients du marché du travail vécus par les immigrants des minorités visibles, plus particulièrement les hommes, nous répartissons les échantillons d'immigrants en trois catégories quant à l'âge : les immigrants qui sont entrés au pays à l'âge de 15 ans et moins ; ceux qui avaient entre 15 et 25 ans ; ceux qui avaient 25 ans et plus. L'expérience de travail et la scolarité du groupe le plus jeune avaient été acquises en grande partie au Canada, alors que la majeure partie de la scolarité et de l'expérience de travail avaient été acquises dans leur pays d'origine pour le groupe des plus vieux. La ventilation pour les hommes démontre que les caractéristiques liées à la productivité rendent compte de seulement 51,3 pour cent de l'écart constaté chez les plus vieux, de 59,6 pour cent chez ceux d'âge moyen, de 88,8 pour cent chez les plus jeunes. Les différentiels des gains ajustés qui en découlent s'établissent à $0,819,0,862$ et 0,953 respectivement. Une analyse détaillée des structures de gains montre que l'expérience de travail chez les immigrants plus vieux demeure sous-évaluée. Chez les plus jeunes récemment entrés, il n'existe pas de preuve à l'effet que la rémunération tenant compte de l'expérience, de la scolarité et du nombre d'années depuis l'entrée présente des différences significatives chez les Blancs et chez les immigrants de sexe masculin. Les données pour les immigrantes sont moins certaines.

Notre analyse des groupes des minorités ethniques montre des déficits au niveau des gains de l'ordre de 20,0 pour cent, de 12,1 pour cent et de 10,9 pour cent chez les Noirs, les Asiatiques du Sud et les Chinois respectivement. Parmi les hommes nés au pays, des structures d'écart de rémunération réduisent les gains des Noirs et des Chinois de sexe masculin d'un pourcentage qui s'établit à 14,0 pour cent et 5,7 pour cent respectivement, mais elles accroissent de 2,0 pour cent les gains relatifs des hommes de l'Asie du Sud. Ces derniers présentent des différences surtout au passage des générations d'immigrants et de personnes nées au pays. La perte au plan de la rémunération attribuable aux structures différentes diminue de 6,0 pour cent chez les Noirs, de 6,4 pour cent chez les Chinois et de 
12,9 pour cent chez les personnes du Sud-Asiatique. Les différentiels de rémunération sont très modestes chez les immigrantes du Sud-Asiatique et de Chine et chez les femmes nées au pays. Les gains relatifs des femmes immigrantes de race noire et de celles nées au pays sont plus faibles de 8,8 pour cent et de 5,8 pour cent respectivement. Par contre, les femmes chinoises nées au pays obtiennent une prime de 3,7 pour cent pour des caractéristiques liées à leur productivité.

Brièvement, bien que nous constations que les minorités visibles soient l'un des groupes désavantagés sur le marché du travail au Canada, nos observations méritent d'être grandement nuancées. Les imperfections du marché du travail sont largement limitées aux immigrants de sexe masculin. Ceux qui sont le plus affectés appartiennent au groupe le plus âgé au moment de l'immigration. Les désavantages en termes de rémunération des hommes nés au pays appartenant à une minorité et des immigrantes ne sont pas seulement modestes, mais ils peuvent être entièrement attribués à la présence de la minorité ethnique noire. Il n'y aucune preuve d'un désavantage au plan de la rémunération chez les femmes nées au pays et appartenant à une minorité. Les désavantages apparaissent le plus critique chez les Noirs (immigrants de sexe masculin) indépendamment de l'âge de l'immigration et chez les Noirs nés au pays. Ces observations viennent corroborer celles qu'on retrouve dans plusieurs études antérieures. Les minorités visibles constituent un groupe diversifié. Les législateurs qui se préoccupent des gains relatifs de ce segment croissant du marché du travail au Canada devraient tenir compte d'une telle diversité. 